\title{
Chemical Composition of Saudi Arabian Sukkari variety of Date Seed Oil and Extracts Obtained by Slow Pyrolysis
}

\author{
A. QADIR, S. P. SINGH, J. AKHTAR, A. ALI ${ }^{1}$ AND M. ARIF*
}

Faculty of Pharmacy, Integral University, Lucknow-226 026, ${ }^{1}$ Faculty of Science, Jamia Hamdard (Hamdard University), New Delhi-110 062, India

Qadir et al.: Composition of Saudi Arabian Sukkari variety of Date Seed Oil

\begin{abstract}
The present study was designed to convert Saudi Arabian Sukkari waste date seeds into pyrolysis liquid char oil in a slow pyrolysis reactor and determine the phytoconstituents by gas chromatography/mass spectrometry. The date seed in particle form was pyrolysed in an externally heated pan sand bath to obtain $5.2 \% \mathrm{v} / \mathrm{w}$ liquid char oil. The liquid char oil $(20 \mathrm{ml})$ was dissolved in $100 \mathrm{ml}$ aqueous methanol (30:70) and was four times fractionated with $25 \mathrm{ml}$ of $\mathrm{n}$-hexane. Small portion $(1 \mathrm{~g})$ of both methanol and $\mathrm{n}$-hexane fraction was subjected to gas chromatography/mass spectrometry analysis. Phytochemical screening of both fractions revealed the presence of steroids, alkaloids, reducing sugars, phenolics, flavonoids, terpenoids, fatty acids and amino acids. The prevailing compounds found in $\mathbf{n}$-hexane fraction were cyclolanost-24-en3-ol (11.25 \%), stigmast-5-en-3 $\beta-0 l$ (2.02 \%), lupen-3-one (3.50 \%), isopropyl myristate $(0.64 \%)$, palmitic acid, methyl ester $(0.74 \%)$, oleic acid $(0.77 \%)$, tridecane $(5.66 \%)$, and dodecane $(4.42 \%)$. Compounds found in methanol fraction were mainly stigmast-5-en-3-ol (5.77 \%), propylene glycol monooleate (2.82 \%), guanosine (35.92 \%), DL-arabinitol (2.11 \%), dodecanoic acid (8.14 \%), stearic acid (4.22 \%), palmitic acid (7.61\%), oleic acid $(9.13 \%)$, 1,3,5-triazine-2,4,6-triamine (1.87\%) and 2-butylbutanoic acid (1.01\%). The presence of these bioactive compounds confirmed the application of the Sukkari varieties of date seeds for various medicinal activities in future drug discovery system and could be analysed for antiinflammatory, antioxidant, cardiovascular, anticancer and immunosuppressant activities. However, isolation of individual phytochemical constituents may proceed to find a novel drug.
\end{abstract}

Key words: Date seed oil, pyrolysis, liquid char oil, gas chromatography/mass spectrometry (GC/MS), phytoconstituents

Date palm (Phoenix dactylifera L.) is an important agricultural commodity and has been cultivated extensively in the whole world especially in North Africa, Middle East, as well as some parts of Central and South America and Southern Europe ${ }^{[1]}$. Date fruit has always been considered an ideal food complement and a rich source of carbohydrate due to its high sugar, dietary fibre, macro and micro-nutrient contents for people of the Middle East ${ }^{[2]}$. Date palm is an important fruit crop in the Kingdom of Saudi Arabia and Sukkari variety of date palm contained the highest amount of protein and nutrients ${ }^{[3]}$. Date seeds also have potential positive health benefits and contain components with different biological actions, such as antiinflammatory, antiviral, antioxidant and some other activities but it is usually wasted ${ }^{[4,5]}$. The date seeds oil is a mixture of different types of major and minor organic compounds

*Address for correspondence E-mail: arif_sweet@rediffmail.com those belong to acids, alcohols, ketones, aldehydes, phenols, ethers, esters, sugars, furans, nitrogen compounds and multifunctional compounds ${ }^{[6]}$. The date seeds are too hard to extract out the constituents and almost unutilized. This waste seed oil can be extracted by slow pyrolysis method and used for different medicinal purpose. Pyrolysis is generally described as the thermal decomposition of the organic components into liquid products ${ }^{[7]}$. In this study, pyrolysis of Sukkari variety of date seeds cultivated in Saudi Arabia are carried out and after purification

This is an open access article distributed under the terms of the Creative Commons Attribution-NonCommercial-ShareAlike 3.0 License, which allows others to remix, tweak, and build upon the work non-commercially, as long as the author is credited and the new creations are licensed under the identical terms

Accepted 08 July 2018

Revised 10 Novemebr 2017

Received 01 February 2017

Indian J Pharm Sci 2018;80(5):940-946 
of liquid char oil products, its phytoconstituents was determined by the sophisticated analytical instruments gas chromatography/mass spectrometry (GC/MS). The underlying components in a date seeds in detail could be characterized and the valuable components would be utilized in pharmaceutical and nutraceutical industry in best possible way to minimize this waste.

Sukkari variety of date seed was directly obtained from date fruit in March 2015 in full ripe condition from Al-Madinah Al-Monwarah city markets of Saudi Arabia and was authenticated in the Department of Pharmacognosy and Phytochemistry, College of Pharmacy, Sattam Bin Abdul Aziz University, KSA (The accession no. PSA/PHAR/COG/15/04). The seeds were washed and dried at about $40^{\circ}$ to remove the remaining moisture present and weighed.

Pyrolysis of date seeds was carried out according to the method of Islam et al., with some modifications ${ }^{[8]}$. At the beginning of experiment, $100 \mathrm{~g}$ of the seeds were milled in a heavy-duty grinder to obtain a coarse powder, which was loaded into glass funnel placed in a pan sand bath. The sand bath was heated to 400$500^{\circ}$ with a burner for pyrolysis and the temperature was measured by means of a mercury thermometer. Simultaneously, the glass funnel containing sample was covered with another glass funnel to prevent the excess loss of sample moisture. To release the constituents and oil, distilled water was added drop-wise to the sample. During pyrolysis, the tar and oil released were collected in a container ${ }^{[8,9]}$.

The products obtained from the pyrolysis of date seed were $5.2 \% \mathrm{v} / \mathrm{w}$ liquid char oil. The liquid char oil $(20 \mathrm{ml})$ was dissolved in $100 \mathrm{ml}$ aqueous methanol (30:70) and it was four times fractionated with $25 \mathrm{ml}$ of $\mathrm{n}$-hexane (Merck, for analysis) by using a separating funnel. After fractionation, layer of methanol and n-hexane was separated and the solvent was removed using a Rota-vap apparatus. In the methanol fraction chocolaty brown colour extract and in n-hexane fraction, white-coloured oily substance was obtained. The physical characteristics like viscosity, refractive index and density of the both fractions of pyrolysis liquid char oil of seeds were evaluated. Viscosity was determined as such without dilution at $27^{\circ}$ using Brookfield DV-1 Prime viscometer (Brookfield Engineering, Inc., Middleboro, MA). The refractive index was measured by using Abbe Refractometer (BESTO) by placing one drop sample on slide and the refractometer was adjusted first with distilled water. Density of the sample was determined using Puchnometer Kit (Adam Equipment co. LTD. Bond Avenue Denbigh East Estate Milton Keynes, MK, ISV-United Kingdom $)^{[10]}$. Small portion $(1 \mathrm{~g})$ of both fractions was subjected to GC/MS analysis ${ }^{[11,12]}$.

Both methanol and n-hexane fractions of pyrolyzed seeds were subjected to preliminary phytochemical investigation for the presence of various phytoconstituents like steroids, alkaloids, reducing sugar, phenolic compounds, flavonoids, saponins, tannins, anthraquinone and amino acids ${ }^{[13]}$.

The GC/MS analysis of both fractions B and C were performed using the GC/MS-QP2010 Ultra. TR 5-MS capillary standard non-polar column, with dimensions of $30 \mathrm{~m}$ and $0.25 \mathrm{~mm}$ id, and $0.25 \mathrm{~mm}$ film was used and flow rate of mobile phase (He as carrier gas) was set at $1.21 \mathrm{ml} / \mathrm{min}$. The oven temperature of GC instrument was raised from $100^{\circ}$ to $260^{\circ}$ at $10^{\circ} / \mathrm{min}$ and injection volume was $5 \mu 1$. Samples which dissolved in n-hexane and methanol were run fully at a range of $10-850 \mathrm{~m} / \mathrm{z}$ and the results were compared by using Wiley spectral library search program. The mass spectra detected in 30-35 $\min ^{[14]}$. The name, molecular weight, molecular formula and structure of the component of test materials were determined while the relative percentage amount of each component was calculated by comparing its average peak area to the total areas.

The relative percent weight compared with the weight of the fresh fruits, crude fibre contents and total ash of date seeds were evaluated. The date seed was successfully converted into liquid char oil by slow pyrolysis system. The contiguous parameters like $\mathrm{pH}$, density and kinematic viscosity of n-hexane and methanolic fractions of pyrolysis liquid char oil were presented in Table 1. Both fractions of pyrolysis oil are found to be slightly heavier than water with a density of 1052.4 and $1036.8 \mathrm{~kg} / \mathrm{m}^{3}$ at $27^{\circ}$. Preliminary phytochemical screening of pyrolysis liquid char fractions of date seeds revealed that the n-hexane fraction contains steroids, terpenoids, amino acids and fatty compounds, whereas methanolic fraction contains steroids, terpenoids, alkaloids, reducing sugars, phenolics, flavonoids, tannins and amino acids compounds.

The extraction, isolation and investigation of plant material play a vital role in the development, modernization, and quality control of herbal formulations. Hence, the present study was intended to find the bioactive compounds present in the liquid 
char oil obtained by slow pyrolysis of date seeds using GC-MS. Crude liquid char oil contained both polar and non-polar phytoconstituents. Sequential fractionation with n-hexane helped in separation of polar and nonpolar phytoconstituents in the respective methanol and n-hexane solvent. The results pertaining to
$\mathrm{GC} / \mathrm{MS}$ analysis led to the identification of a number of compounds from GC and they were identified through mass spectrometry attached with GC/MS analysis. The chromatograms obtained by $\mathrm{n}$-hexane and methanol fractions of liquid char oil were shown in fig. 1A and $\mathrm{B}$, respectively. The active principle, area of the peak,

TABLE 1: PHYSICOCHEMICAL CHARACTERISTICS OF DATE SEEDS AND METHANOL AND n-HEXANE FRACTIONS OF PYROLYSIS LIQUID CHAR OIL

\begin{tabular}{lcccccc}
\hline Sample & $\begin{array}{c}\text { Percentage } \\
\text { weight (\%) }\end{array}$ & Crude fibre (\%) & $\begin{array}{c}\text { Ash } \\
(\%)\end{array}$ & $\begin{array}{c}\text { Refractive } \\
\text { index at } 27^{\circ}\end{array}$ & $\begin{array}{c}\text { Density } \\
\left(\mathbf{k g} / \mathrm{m}^{3}\right)\end{array}$ & $\begin{array}{c}\text { Kinematic viscosity at } \\
\mathbf{2 7 ^ { \circ }} \text { (cSt) }\end{array}$ \\
\hline Seed & 11.27 & 42.4 & 3.4 & -- & -- & -- \\
Methanol fraction & 2.8 & -- & -- & 1.442 & 1052.4 & 7.68 \\
n-Hexane fraction & 1.36 & -- & -- & 1.468 & 1036.8 & 6.24 \\
\hline
\end{tabular}
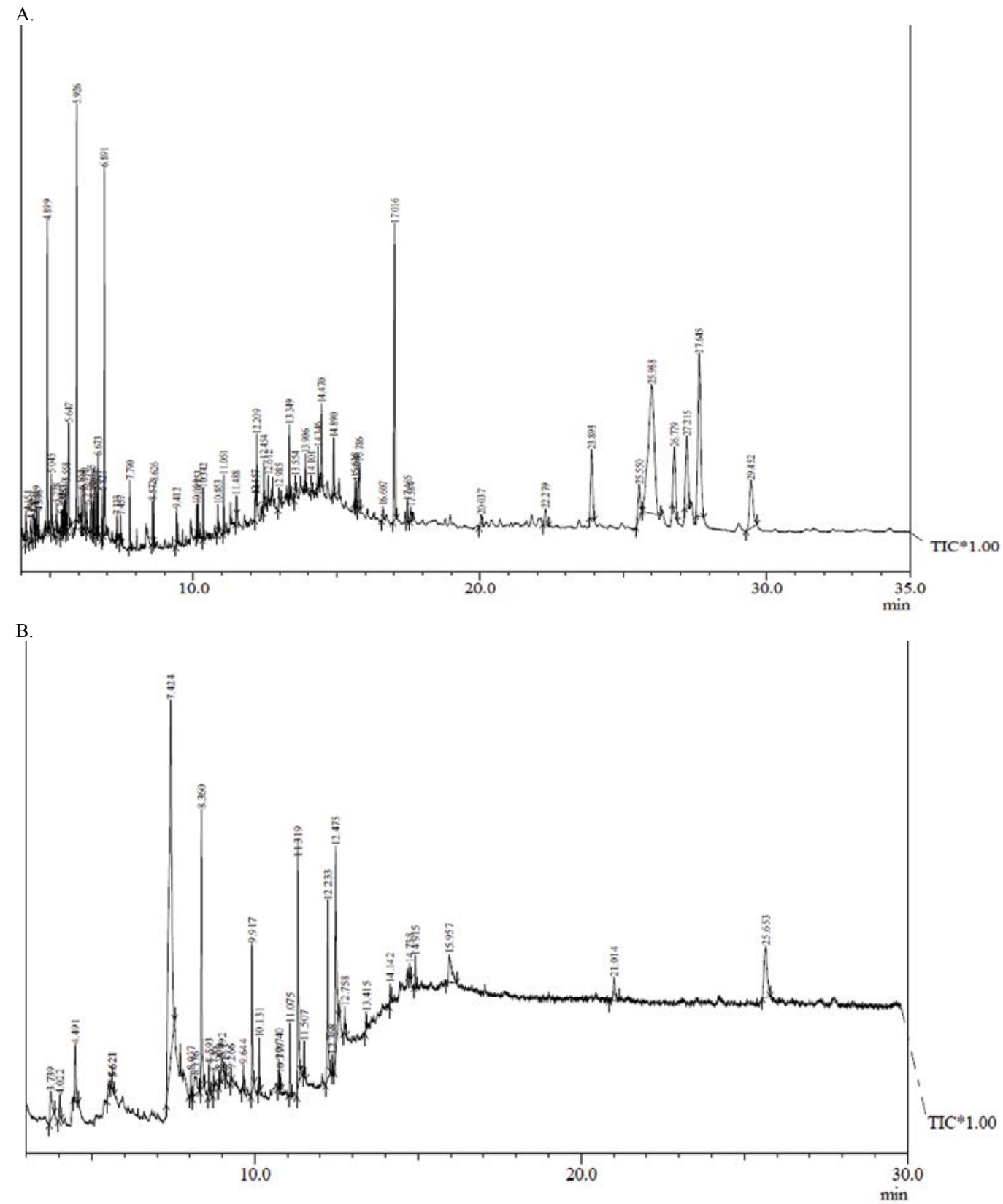

Fig. 1: GC/MS chromatograms

A: n-hexane and B: methanol fraction of pyrolysis liquid char oil of Sukkari date seeds 
concentration (\%), and retention time and details of the compounds were presented in Tables 2 and 3, respectively.
The prevailing compounds found in the n-hexane fraction were steroidal and triterpenoids (cyclolanost24-en-3-ol, $11.25 \%$; stigmast-5-en-3 $\beta$-ol, $2.02 \%$;

TABLE 2: COMPOUNDS PRESENT IN THE n-HEXANE FRACTION OF PYROLYSIS LIQUID CHAR OIL OF SUKKARI DATE SEEDS USING GC/MS ANALYSIS

\begin{tabular}{|c|c|c|c|c|c|}
\hline RT & Peak area, \% & Name of compounds & $\begin{array}{l}\text { Molecular } \\
\text { formula }\end{array}$ & $\begin{array}{l}\text { Molecular } \\
\text { weight }\end{array}$ & Compounds nature \\
\hline 4.151 & 0.59 & Tetramethyl-2-hexadecen-1-ol & $\mathrm{C}_{20} \mathrm{H}_{40} \mathrm{O}$ & 296 & Phytol \\
\hline 4.330 & 0.44 & (14Z)-14-tricosenyl formate & $\mathrm{C}_{24} \mathrm{H}_{46} \mathrm{O}_{2}$ & 366 & Fatty ester \\
\hline 4.429 & 0.46 & 5-ethyl-undecane & & 184 & Hydrocarbon \\
\hline 4.899 & 4.42 & Dodecane & $\mathrm{C}_{16} \mathrm{H}_{34}$ & 226 & Hydrocarbon \\
\hline 5.045 & 0.75 & 2,5-dimethyl undecane & $\mathrm{C}_{13} \mathrm{H}_{28}$ & 184 & Hydrocarbon \\
\hline 5.228 & 0.38 & 2-ethylhexyl acrylate & $\mathrm{C}_{11} \mathrm{H}_{20} \mathrm{O}_{2}$ & 184 & Acrylic acid ester \\
\hline 5.390 & 0.39 & Hexyl cyclohexane & & 168 & Hydrocarbon \\
\hline 5.510 & 0.38 & 4-methyl dodecane & $\mathrm{C}_{13} \mathrm{H}_{28}$ & 184 & Hydrocarbon \\
\hline 5.558 & 0.70 & 2-methyl-6-propyl dodecane & $\mathrm{C}_{16} \mathrm{H}_{34}$ & 226 & Hydrocarbon \\
\hline 5.647 & 2.12 & 2,6,10,14-tetramethyl pentadecane & $\mathrm{C}_{19} \mathrm{H}_{40}$ & 268 & Hydrocarbon \\
\hline 5.926 & 5.66 & Tridecane & $\mathrm{C}_{13} \mathrm{H}_{28}$ & 184 & Hydrocarbon \\
\hline 6.104 & 0.70 & 3-bromodecane & $\mathrm{C}_{10} \mathrm{H}_{21} \mathrm{Br}$ & 220 & Hydrocarbon \\
\hline 6.190 & 0.74 & 2,4-decadienal, $(\mathrm{E}, \mathrm{E})$ & & 152 & Aldehyde \\
\hline 6.277 & 0.46 & 1-methyl naphthalene & & 142 & Naphthalene \\
\hline 6.425 & 1.02 & 1-propyldecyl cyclohexane & $\mathrm{C}_{19} \mathrm{H}_{38}$ & 266 & Hydrocarbon \\
\hline 6.498 & 0.40 & 4-methyl tridecane & $\mathrm{C}_{14} \mathrm{H}_{30}$ & 198 & Hydrocarbon \\
\hline 6.617 & 0.56 & 3,8-dimethyl-decane & $\mathrm{C}_{12} \mathrm{H}_{26}$ & 170 & Hydrocarbon \\
\hline 6.673 & 0.96 & 2,6,10,14-tetramethyl-hexadecane & & 282 & Hydrocarbon \\
\hline 6.821 & 0.63 & 1-tetradecanol & $\mathrm{C}_{14} \mathrm{H}_{30} \mathrm{O}$ & 214 & Alcohol \\
\hline 7.333 & 0.32 & 1,8-dimethyl-naphthalene & $\mathrm{C}_{12} \mathrm{H}_{12}$ & 156 & Naphthalene \\
\hline 7.457 & 0.37 & $2,6,10,15$-tetramethyl-heptadecane & $\mathrm{C}_{21} \mathrm{H}_{44}$ & 296 & Hydrocarbon \\
\hline 8.572 & 0.54 & n-pentadecanol & $\mathrm{C}_{15} \mathrm{H}_{32} \mathrm{O}$ & 228 & Alcohol \\
\hline 10.109 & 0.36 & n-nonadecanol-1 & $\mathrm{C}_{19} \mathrm{H}_{40} \mathrm{O}$ & 284 & Alcohol \\
\hline 10.342 & 0.64 & Isopropyl myristate & $\mathrm{C}_{17} \mathrm{H}_{34} \mathrm{O}_{2}$ & 270 & Fatty acid ester \\
\hline 11.051 & 0.74 & Palmitic acid, methyl ester & $\mathrm{C}_{17} \mathrm{H}_{34} \mathrm{O}_{2}$ & 270 & Fatty acid ester \\
\hline 11.488 & 0.29 & 1-Pentyl-2-propyl-cyclopentane & & 182 & Hydrocarbon \\
\hline 12.157 & 0.23 & 2,6,10,14-tetramethyl-(Phytan) & $\mathrm{C}_{20} \mathrm{H}_{42}$ & 282 & Phytan \\
\hline 12.254 & 0.77 & Oleic acid & $\mathrm{C}_{18} \mathrm{H}_{34} \mathrm{O}_{2}$ & 282 & Fatty acid \\
\hline 12.612 & 0.34 & 9-Octadecenoic acid (Z)-, ethyl ester & $\mathrm{C}_{20} \mathrm{H}_{38} \mathrm{O}_{2}$ & 310 & Fatty acid ester \\
\hline 13.349 & 0.84 & Docosane & & 310 & Hydrocarbon \\
\hline 13.906 & 0.45 & Tetratetracontane & & 618 & Hydrocarbon \\
\hline 14.346 & 0.54 & Arachidic alcohol & $\mathrm{C}_{20} \mathrm{H}_{42} \mathrm{O}$ & 298 & Fatty alcohol \\
\hline 14.470 & 1.03 & Hexatriacontane & $\mathrm{C}_{36} \mathrm{H}_{74}$ & 506 & Hydrocarbon \\
\hline 14.890 & 0.90 & Diisooctyl phthalate & $\mathrm{C}_{24} \mathrm{H}_{38} \mathrm{O}_{4}$ & 390 & Ester \\
\hline 15.784 & 1.21 & n-tetratetracontane & & 618 & Alkane \\
\hline 16.607 & 0.32 & 2-methylhexacosane & & 380 & Hydrocarbon \\
\hline 17.016 & 6.71 & Squalene & $\mathrm{C}_{30} \mathrm{H}_{50}$ & 410 & Terpenoids \\
\hline 17.465 & 0.49 & Henicosyl formate & $\mathrm{C}_{22} \mathrm{H}_{44} \mathrm{O}_{2}$ & 340 & Ester \\
\hline 17.584 & 0.37 & Pentatriacontane & $\mathrm{C}_{35} \mathrm{H}_{72}$ & 492 & Hydrocarbon \\
\hline 20.037 & 0.46 & $\begin{array}{c}\text { 2,6,10,15,19,23-hexamethyl-1,6,10,14,18,22- } \\
\text { tetracosahexaen-3-ol }\end{array}$ & & 426 & Terpenol \\
\hline 23.89 & 3.50 & Lupen-3-one & $\mathrm{C}_{30} \mathrm{H}_{48} \mathrm{O}$ & 424 & Lupen \\
\hline 25.550 & 2.02 & Stigmast-5-en-3 B-ol & $\mathrm{C}_{29} \mathrm{H}_{50} \mathrm{O}$ & 414 & Steroid \\
\hline 26.779 & 3.50 & $\begin{array}{l}\text { Propanoic acid, 2,2-dimethyl-, [(E,E)-3,7,11- } \\
\text { trimethyl-2,6,10-dodecatrien-1-yl] ester }\end{array}$ & $\mathrm{C}_{20} \mathrm{H}_{34} \mathrm{O}_{2}$ & 306 & Terpene ester \\
\hline 27.215 & 4.11 & 9,19-cyclolanost-23-ene 3 B,25-diol & $\mathrm{C}_{30} \mathrm{H}_{50} \mathrm{O}_{2}$ & 442 & Steroid \\
\hline 27.645 & 11.25 & 9, 19-cyclolanost-24-en-3-ol, (3.B) & $\mathrm{C}_{30} \mathrm{H}_{50} \mathrm{O}$ & 426 & Steroid \\
\hline 29.452 & 4.10 & 13,27-cycloursan-3-one & $\mathrm{C}_{30} \mathrm{H}_{48} \mathrm{O}$ & 424 & Steroid \\
\hline
\end{tabular}



SUKKARI DATE SEEDS USING GC/MS ANALYSIS

\begin{tabular}{|c|c|c|c|c|c|}
\hline RT & $\begin{array}{l}\text { Peak area } \\
\%\end{array}$ & Name of compounds & $\begin{array}{l}\text { Molecular } \\
\text { formula }\end{array}$ & $\begin{array}{l}\text { Molecular } \\
\text { weight }\end{array}$ & Compounds nature \\
\hline 3.739 & 1.87 & 1,3,5-triazine-2,4,6-triamine & $\mathrm{C}_{3} \mathrm{H}_{6} \mathrm{~N}_{6}$ & 126 & Aza dye \\
\hline 4.022 & 1.01 & 2-butylbutanoic acid & $\mathrm{C}_{8} \mathrm{H}_{16} \mathrm{O}_{2}$ & 144 & Fatty acid \\
\hline 4.491 & 2.05 & $\begin{array}{l}\text { 2,3-dihydro-3,5-dihydroxy-6-methyl-pyran-4- } \\
\text { one }\end{array}$ & $\mathrm{C}_{6} \mathrm{H}_{8} \mathrm{O}_{4}$ & 144 & Flavone \\
\hline 5.621 & 0.42 & Pelargonic acid & $\mathrm{C}_{9} \mathrm{H}_{18} \mathrm{O}_{2}$ & 158 & Fatty acid \\
\hline 5.621 & 0.54 & (3,3,4-trimethyl-4-pentenyl) benzene & $\mathrm{C}_{14} \mathrm{H}_{20}$ & 188 & Aromatic \\
\hline 7.424 & 35.92 & Guanosine & $\mathrm{C}_{10} \mathrm{H}_{13} \mathrm{~N}_{5} \mathrm{O}_{5}$ & 283 & Nucleoside \\
\hline 8.037 & 0.44 & Methyl laurinate & $\mathrm{C}_{13} \mathrm{H}_{26} \mathrm{O}_{2}$ & 214 & Fatty ester \\
\hline 8.176 & 2.11 & DL-arabinitol & $\mathrm{C}_{5} \mathrm{H}_{12} \mathrm{O}_{5}$ & 152 & Sugar \\
\hline 8.360 & 8.14 & Dodecanoicacid & $\mathrm{C}_{12} \mathrm{H}_{24} \mathrm{O}_{2}$ & 200 & Fatty acid \\
\hline 8.593 & 0.70 & n-pentadecanol & $\mathrm{C}_{15} \mathrm{H}_{32} \mathrm{O}$ & 228 & Fatty alcohol \\
\hline 8.736 & 0.34 & Phthalic acid, ethyl isoporpyl ester & $\mathrm{C}_{13} \mathrm{H}_{16} \mathrm{O}_{4}$ & 236 & Ester \\
\hline 8.909 & 0.25 & 1,2,4-trimethoxy-5-[(1E)-1-propenyl] benzene & $\mathrm{C}_{12} \mathrm{H}_{16} \mathrm{O}_{3}$ & 208 & Camphor \\
\hline 8.992 & 1.22 & $\begin{array}{l}\text { 4,6-dimethyl-3-([(E)-(3-itrophenyl) } \\
\text { methylidene] amino)-2(1H)-pyridinone }\end{array}$ & $\mathrm{C}_{14} \mathrm{H}_{13} \mathrm{~N}_{3} \mathrm{O}_{3}$ & 271 & Alkaloids \\
\hline 9.113 & 0.10 & Mandelic acid, 3,4-dihydroxy, (4-TMS) & $\mathrm{C}_{24} \mathrm{H}_{34} \mathrm{~F}_{5} \mathrm{NO}_{3} \mathrm{Si}_{3}$ & 563 & Organo-silicates \\
\hline 9.266 & 0.23 & Vinyl octanoate & $\mathrm{C}_{10} \mathrm{H}_{18} \mathrm{O}_{2}$ & 170 & Ester \\
\hline 9.644 & 0.56 & Methyl tetradecanoate & $\mathrm{C}_{15} \mathrm{H}_{30} \mathrm{O}_{2}$ & 242 & Ester \\
\hline 9.917 & 4.22 & Stearic acid & $\mathrm{C}_{18} \mathrm{H}_{36} \mathrm{O}_{2}$ & 284 & Fatty acid \\
\hline 10.131 & 1.01 & n-nonadecanol-1 & $\mathrm{C}_{19}^{10} \mathrm{H}_{40} \mathrm{O}$ & 284 & Wax alcohol \\
\hline 10.740 & 0.52 & 8-octadecanone & $\mathrm{C}_{18} \mathrm{H}_{36} \mathrm{O}$ & 268 & Wax ketone \\
\hline 10.777 & 0.14 & Phthalic acid, butyl tetradecyl ester & $\mathrm{C}_{16} \mathrm{H}_{22} \mathrm{O}_{4}$ & 278 & Aromatic ester \\
\hline 11.075 & 1.56 & Methyl palmitate & $\mathrm{C}_{17} \mathrm{H}_{34} \mathrm{O}_{2}$ & 270 & Fatty ester \\
\hline 11.319 & 7.61 & Palmitic acid & $\mathrm{C}_{16} \mathrm{H}_{32} \mathrm{O}_{2}$ & 256 & Fatty acid \\
\hline 11.507 & 0.77 & n-Nonadecanol-1 & $\mathrm{C}_{19} \mathrm{H}_{40} \mathrm{O}$ & 284 & Dehydag wax \\
\hline 12.233 & 5.83 & Methyl 8-octadecenoate & $\mathrm{C}_{19} \mathrm{H}_{36} \mathrm{O}_{2}$ & 296 & Fatty ester \\
\hline 12.368 & 0.35 & Methyl stearate & $\mathrm{C}_{19} \mathrm{H}_{38} \mathrm{O}_{2}$ & 298 & Fatty ester \\
\hline 12.475 & 9.13 & Oleic acid & $\mathrm{C}_{18} \mathrm{H}_{34} \mathrm{O}_{2}$ & 282 & Fatty acid \\
\hline 12.758 & 0.76 & 9-tricosene, $(Z)$ & $\mathrm{C}_{23} \mathrm{H}_{46}$ & 322 & Hydrocarbon \\
\hline 13.415 & 0.50 & Decanoylchloride & $\mathrm{C}_{10} \mathrm{H}_{19} \mathrm{ClO}$ & 190 & Acid salt \\
\hline 14.142 & 0.52 & Myristaldehyde & $\mathrm{C}_{16} \mathrm{H}_{32} \mathrm{O}$ & 240 & Fatty aldehyde \\
\hline 14.738 & 0.21 & 2-azidocholestan-3-ol & $\mathrm{C}_{27}^{10} \mathrm{H}_{47} \mathrm{O}$ & 508 & Steroid \\
\hline 14.915 & 0.86 & Isooctyl phthalate & $\mathrm{C}_{24} \mathrm{H}_{38} \mathrm{O}_{4}$ & 390 & Aromatic ester \\
\hline 15.957 & 2.82 & Propylene glycol monooleate & $\mathrm{C}_{21}^{24} \mathrm{H}_{40} \mathrm{O}_{3}$ & 340 & Fatty ester \\
\hline 21.014 & 1.53 & Stigmast-5-en-3-yl 9-octadecenoate & $\mathrm{C}_{47} \mathrm{H}_{82} \mathrm{O}_{2}$ & 678 & Steroidal ester \\
\hline 25.653 & 5.77 & Stigmast-5-en-3-ol, (3.B) & $\mathrm{C}_{29}^{47} \mathrm{H}_{50} \mathrm{O}^{2}$ & 414 & Steroid \\
\hline
\end{tabular}

lupen-3-one, $3.50 \%$; squalene, $6.71 \%$ ), various fatty acids (palmitic acid, methyl ester, $0.74 \%$; oleic acid, $0.77 \%$; isopropyl myristate, $0.64 \%$ ), and various hydrocarbons tridecane $(5.66 \%)$ and dodecane (4.42\%). Compounds found in methanol fraction were mainly steroids (stigmast-5-en-3-ol, $5.77 \%$ ), glycerol (propylene glycol monooleate, $2.82 \%$ ), purine base (guanosine, $35.92 \%$ ), sugar (DL-arabinitol, $2.11 \%$; 2,3-dihydro-3,5-dihydroxy-6-methyl-4h-pyran-4one, $2.05 \%$ ), fatty acids (dodecanoic acid, $8.14 \%$; stearic acid, $4.22 \%$; palmitic acid, $7.61 \%$; oleic acid, $9.13 \%$; 2-butylbutanoic acid, $1.01 \%$ ) and aza dye (1,3,5-triazine-2,4,6-triamine, $1.87 \%)$.
The n-hexane oily fraction of liquid char oil was a semisolid at temperatures below $10^{\circ}$ and a viscous liquid at room temperature. The semi-solid nature of the oils is an indication of the presence of major saturated and unsaturated fatty acids in sample ${ }^{[15]}$. In the GC/MS analysis of the both fractions of pyrolysis liquid char oil were found the different types of important chemical constituents, which were the saturated and unsaturated fatty acid esters, steroids and terpenoid compounds, they were previously reported in literature ${ }^{[10]}$. Fatty acids like palmitic acid, stearic acid and oleic acid (omega-9) were mainly observed in both fractions. MS spectra of these saturated and unsaturated fatty acids 
were readily identified by their high resolution masses 256, 284 and 282 with predicted molecular formulas of $\mathrm{C}_{16} \mathrm{H}_{32} \mathrm{O}_{2}, \mathrm{C}_{18} \mathrm{H}_{36} \mathrm{O}_{2}$ and $\mathrm{C}_{18} \mathrm{H}_{34} \mathrm{O}_{2}$, respectively. Five steroids were also identified along with propylene glycol monooleate (fatty acid ester) and three terpenoids like squalene, trimethyl-2,6,10-dodecatrien-1-yl (propanoic acid terpenes ester) and lupen-3-one and a number of saturated and unsaturated long chain alcohols. $\beta$-Sitosterol was found to be the most abundant of the steroids followed by stigmast-5-en-3-ol, cyclolanost23-ene-3,25-diol, cycloursan-3-one, stigmast-5-en-3yl 9-octadecenoate and 2-azidocholestan-3-ol.

These terpenoids and steroidal compounds have several important medicinal activities in future drug discovery system. Such as lanostane triterpenoid and steroidal compounds have significant adaptogenic and anabolic activity. They enhance the general performance of organism during the stress condition by normalizing the physiological process and various functions of body ${ }^{[16]}$. On the other hand organic acids (octadecenoic acid, pelargonic acid and butylbutanoic acid), flavonoids and esters of aromatic phenolic compounds have been reported to exhibit a wide range of biological activities such as antioxidant, antimicrobial and mast cells stabilizing properties ${ }^{[17]}$. The fractionated oil could be used in cosmetics and other pharmaceutical care products due to the presence of fatty acids such as palmitic acid, stearic acid and oleic acid in the oil ${ }^{[18]}$. The stearic and oleic acid content in date seed oil could make this oil as effective percutaneous absorption enhancer by enhancing the diffusion of lipophilic nonsteroidal antiinflammatory drugs, which have been widely used in conditions such as chronic rheumatic disorders treatment ${ }^{[19]}$. The presence of different components in oil such as steroids, terpenoids, organic acids, flavonoids and esters of aromatic phenolic compounds can augment antiinflammatory and analgesics potency of the pharmaceutical preparations. Oleic acid as such taken in diet has augmented the high density lipoprotein content in blood and lowered the low density lipoprotein cholesterol and lipid content showing antiatherosclerotic effect ${ }^{[20]}$. This property could prevent cardiovascular diseases. Therefore, the fractionated date seed oil could be exploited by the pharmaceutical industries to develop drug formulations for the treatment of different cardiovascular and chronic rheumatic disorders.

The Sukkari variety of Saudi Arabian date seed was successfully converted into liquid char oil by slow pyrolysis system. GC/MS data of both fractions of date seeds contained major compounds. These compounds may have important medicinal activities. Phytochemical and GC/MS analysis showed several bioactive compounds including steroids, flavonoids, terpenoids, fatty acids and different types of aromatic ester compounds. These constituents might demonstrate certain pharmacological activities like antiatherosclerotic, antiinflammatory, analgesic and antirheumatic activity. Therefore, the pyrolysis liquid char oil from the date seed could be used by pharmaceutical industry for the preparation of topical formulations for the treatment of chronic rheumatic disorders and its purified fatty acids could be considered as an important candidate of potential source for the treatment of cardiovascular disorder. Moreover, GC/ MS profile could be used as biochemical markers in the pharmaceutical industries to identify the different components present in date seeds and in authentication of mother plants.

\section{Acknowledgements:}

Authors wish to thank Dr. Y. T. Kamal, Assistant Professor, Department of Pharmacognosy and Phytochemistry, College of Pharmacy, Sattam Bin Abdul Aziz University, KSA for authenticating the date palm seeds.

\section{REFERENCES}

1. Al-Shahib W, Marshall RJ. The fruit of the date palm: Its possible use as the best food for the future? Int J Food Sci Nutr 2003;54:247-59.

2. Myhara RM, Karkalas J, Taylor MS. The composition of maturing omani dates. J Sci Food Agric 1999;79:1345-50.

3. Saleh EA, Tawfik MS, Abu-Tarboush HM. Phenolic contents and antioxidant activity of various date palm (Phoenix dactylifera L.) fruits from Saudi Arabia. Food Nutr Sci 2011;2:1134-41.

4. Mohamed DA, Al-Okbi SY. In vivo evaluation of antioxidant and antiinflammatory activity of different extracts of date fruits in adjuvant arthritis. Pol J Food Nutr Sci 2004;13:397-402.

5. Jassim SAA, Naji MA. In vitro evaluation of the antiviral activity of an extract of date palm (Phoenix dactylifera L.) pits on a Pseudomonas phage. Evid Based Complement Alternat Med 2010;7(1):57-62.

6. Al Hooti S, Sidhu JS, Qabazard H. Chemical composition of seeds of date fruit cultivars of United Arab Emirates. J Food Sci Technol 1997;35:44-6.

7. Ibarra D, Del Río JC, Gutiérrez A, Rodríguez IM, Romero $\mathrm{J}$, Martínez MJ, et al. Chemical characterization of residual lignins from eucalypt paper pulps. J Anal Appl Pyrol 2005;74:116-22.

8. Islam MN, Ani FN. Characterization of bio-oil from palm shell pyrolysis with catalytic upgrading. World Renewable Energy Congress. Pergamon: Elsevier Science; 1998. p. 1977-99. 
9. Ayll'on M, Aznar M, Anchez JS, Gea G, Arauzo J. Influence of temperature and heating rate on the fixed bed pyrolysis of meat and bone meal. Chem Eng J 2006;121:85-96.

10. Devshony S, Eteshola E, Shani A. Characteristics and some potential applications of date palm (Phoenix dactylifera L.) seeds and seed oil. J Am Oil Chem Soc 1992;69:595-7.

11. Besbes S, Blecker C, Deroanne C, Lognay G, Drira NE, Hamadi A. Heating effects on some quality characteristics of date seed oil. Food Chem 2005;91:469-76.

12. Nostro A, Germano MP, D'angelo V, Marino A, Cannatelli MA. Extraction methods and bioautography for evaluation of medicinal plant antimicrobial activity. Lett Appl Microbiol 2000;30:379-84.

13. Khandelwal KR. Practical Pharmacognosy: Techniques and Experiments. $13^{\text {th }}$ ed. Pune, India: Nirali Prakashan; 2004. p. 149-56.

14. Janakiraman N, Jhonson M, Sahaya Sathis S. GC/MS analysis of bioactive constitutions of Peristrophe bicalyculata (Retz.) Nees. (Acanthaceae). Asian Pac J Trop Biomed 2012;S1:S46eS49.

15. Abdalla RSM, Albasheer AA, ELHussein ARM, Gadkariem
EA. Physico-chemical characteristics of date seed oil grown in Sudan. Am J Appl Sci 2012;9:993-9.

16. Muhammad A, Sheeba F, Talib H, Mohammad A. Adaptogenic activity of lanostane triterpenoid isolated from Carissa carandas fruit against physically and chemically challenged experimental mice. Pharmacogn J 2013;5:216-20.

17. Sachan NK, Arif M, Zaman K, Kumar Y. Antiinflammatory, analgesic and antioxidant potential of the stem bark of Spondias mangifera willd. Arch Biol Sci 2011;63:413-19.

18. Vermaak I, Kamatou GPP, Komane-Mofokeng B, Viljoen AM, Beckett K. African seed oils of commercial importancecosmetic applications. S Afr J Bot 2011;07:3.

19. Larrucea E, Arellano A, Santoyo S, Ygartua P. Combined effect of oleic acid and propylene glycol on the percutaneous penetration of tenoxicam and its retention in the skin. Euro J Pharm Biopharm 2001;52 (2):113-9.

20. Gilmore LA, Walzem RL, Crouse SF, Smith DR, Adams TH, Vaidyanathan $\mathrm{V}$, et al. Consumption of high-oleic acid ground beef increases HDL-cholesterol concentration but both highand low-oleic acid ground beef decrease HDL particle diameter in normocholesterolemic men. J Nutr 2011;141:1188-94. 